\title{
The mirage of "Rainbowism" within the nightmare of \#MustFall campaigns. Exploring the penetrating hermeneutics of compassionate being-with against the background of decolonising activism and xenophobic suspicion
}

\author{
Louw, Daniël \\ North-West University \\ djl@sun.ac.za
}

\begin{abstract}
Decolonising activism in South African is currently oscillating between social disillusionment (disillusionment about the ability to create a new South Africa by means of Constitutional Justice after twenty-two years of hope for a better life for all) and existential pain (internalised anger resulting from experiences of rejection and humiliating oppression). \#MustFall campaigns have become vehicles for the expression of unarticulated feelings of inferiority, suppressed anger and cultural exclusion. It also reveals signs of new forms of racism and increasing exponents of black-white polarisation and xenophobic suspicion. The latter should not be interpreted merely in terms of local modes of radicalization and upcoming modes of political populism, but also against the background of new, global forms of "fear for the other" as expressed in the refugee paranoia and migrant crisis. It becomes a burning pastoral question for communities of faith how to penetrate the bottom line of a possible political cul de sac and cultural intolerance. The question is posed: What is meant by an ecclesial approach within the bleak situation of no-solution-at-all? Instead of a pessimistic retrotopia (back to the past) (Zygmunt Bauman) or an optimistic utopia (the pursuit of happiness in affluent societal projections), the perichoresis of compassionate beingwith is explored within the theological parameters of oiktirmos, rhm, hnn and pathē. It is argued that a pastoral mode of hospitable presence should be implied in order to penetrate the danger of a complete xenophobic deadlock in civil society.
\end{abstract}

Key words

\#MustFall campaigns; anti-white polarisation; theology of compassion; decolonisation; colonial anthropology; retrotopia; pastoral caregiving 


\section{Introduction}

In a letter "To the Independence of Malaysia” (31 $1^{\text {st }}$ August, 1957), Queen Elizabeth II linked decolonisation to the notion of transition, namely from dependence to independence, from empire-control to sovereign freedom (in Osterhammel 1997:112-117). Decolonisation was about freedom and independence from monarchy rule and the British Empire.

However, decolonisation has deeper roots. According to Osterhammel (1997:108), it has its roots in colonialist anthropology which was deeply influenced by the polarity between superior invaders and inferior, uncivilised natives. Colonialism operates according to anthropological counterparts: the construction of inferior "otherness". "The notion that non-Europeans differ utterly and essentially from Europeans was a cornerstone of colonialist thought. The inferior mental and physical abilities imputed to non-Europeans would render them incapable of the large-scale cultural accomplishments and heroic deeds that only modern Europe could achieve" (Osterhammel 1997:108).

Colonisation had been accompanied by racial undertones and class distinctions. Even postcolonial theories and decolonising strategies are still in a very subtle way influenced by masked racial sentiments. The real danger lurks that decolonising propositions, still maintain hegemonic power structures and imperial ideology. For example: "Mediated through racial/ethnic and class antagonisms, the sharpening of class and racial conflicts in the Unites States today has revived a hegemonic project of reconstituting a pluralist multiracial nation that recuperates traditional ideas of individualism and "American exceptionalism" (San Juan 1999:11).

In a report on campus unrest and the \#FeesMustFall activism, the statement has been made that a lack of empathy/compassion, self-centeredness (smugness) and discriminatory privilege are under the most basichampering factors in the social discourse on the riots at universities (Gregan 2016:10). If apathy and a lack of compassion are contributing to the deadlock, the following question should be posed by a pastoral hermeneutics: What are our options in practical theological thinking in the attempt to address the polar deadlock: we (anger of the unprivileged) - them (apathy of the privileged); violent destruction by disillusioned students - withdrawal from integration politics by the frustrated administrators? 
The problem with integration policies is that in most cases they were driven by ideologies regarding national identity that still favour the concerns of majority groups and people in power. Thus, the reason why San Juan (1999:11) asserts: "National identity, however, has always been the political and ideological effect of a managed consensus based on material inequality and hierarchical stratification." And perhaps, this assertion explains why the ideology of the Rainbow Nation is busy becoming a fading mirage.

The euphoria regarding the new dispensation after the hell of apartheid, coined the notion of the Rainbow Nation. However, in the light of the many \#MustFall Campaigns, it seems that the idea of a Rainbow Nation is becoming a mirage. Therefore, the intriguing question: Can we move beyond the current deadlock into a future that can reshape civil societal structures and overcome the attitudinal polarity of apathy - anger? If the existential crisis of distrust is linked to habitus, what would be a constructive approach that gives hope to depleted citizens in South Africa? What can contribute to the bridging of social and societal schisms that are currently contributing to scepticism about the 1990-1994 miracle of a bloodless transition of negotiation: "rainbowism"?

Is it possible that the theological concept of compassion in pastoral encounters can contribute to the creation of forums for dialogue, solidarity and meaningful transformation: moments of "synchronicity" (Jung) (Jaworski 1996). ${ }^{1}$

Before we explore theological options, it is important to analyse and understand the undergirding anthropological assumptions in colonial thinking that contributed to prejudice and xenophobia. The latter should be interpreted within the wider global context of radicalised forms of cultural prejudice and suspicion against the influx of intruding, illegal refugees in North America, Europe and Sub-Saharan Africa.

1 Synchronicity is a concept coined by Jung: events are "meaningful coincidences" if they occur with no causal relationship yet seem to be meaningfully related within daily social encounters. Synchronicity. [Online] Available: https://en.wikepedia.org/wiki/ Synchronicity. [Accessed 16/09/2016]. 


\section{Colonial anthropology}

Colonial anthropology went hand in glove with imperialistic ideology. It can be described as a concept that "comprises all forces and activities contributing to the construction and the maintenance of transcolonial empires. Imperialism presupposes the will and the ability of an imperial centre to define as imperialist own national interests and enforce them worldwide in the anarchy of the international system. Imperialism thus implies not only colonial politics, but international politics for which colonies are not just ends in themselves, but also pawns in global power games" (Osterhammel 1997:21).

The polar tension and cultural difference between superiority and inferiority, was explained in many different ways. Theologically, difference was explained as the depravity of heathens and characteristics emanating from creational diversity as established by God the creator. Within social structures, cultural and creational difference lead to a hierarchy of races and eventually to judicial exploitation of human beings and to the ontological pain of humiliation: "I would like to suggest that the failure to acknowledge and undertake the healing process to address social pain is at the heart of our failure to make the journey from subjects to citizens" (Ramphela 2012:174).

"The lay psychology of colonial expatriates, applied on an everyday basis and continually reaffirmed by the mechanism of the self-fulfilling prophecy, was based on a series of characterological generalizations: the "natives" were said to be lazy, shiftless, cruel, playful, naïve, dissolute, duplicitous, incapable of abstract thought, impulsive, etc." (Osterhammel 1007:109).

One should deal with the fact that colonial anthropology, is most of times framed by many forms of racial prejudice. An example is social breakdowns during the Californian unrests in 1995. According to San Juan (1999:113114), racial prejudice is a core issue in anti-colonial campaigns. Latin American and Asian immigrants were identified as the culprits. "Racism motivates this political movement since it is mainly Latinos and Asians, not the "illegal" Canadian, German, and Scandinavian immigrants jostling with the Orange Country crowd, who targeted for selective enforcement" (San Juan 1999:114). 
In an interview with Tankiso Mamabolo, a drama student and activist at the University of Cape Town, during the 2016 \#MustFall Campaigns, she explained the rationale behind the play The Fall as follows: it is about a social and civil consciousness that expresses institutional racism. The Fall does not merely address direct, blunt racism; it exposes existential inferiority (Janse Van Rensburg 2016:3).

The play addresses the fact that cultural polarisation in South Africa between white smugness (supremacy) and black resistance (inferiority) has deep seated racial tensions as background. Therefore, the focus in decolonisation on the struggle against colonial racism. "Colonial regimes manipulated as well as created ethnic and racial identities" (Loomba 1998:122). Anti-colonial and black resistance struggles thus evoke the discourse of race because perceived and constructed racial differences were transformed into real inequalities by colonist and/or racist regimes and ideologies (Loomba 1998:123).

The new dispensation of an excellent constitution that should safeguard basic human rights for all, does not suffice and is not anymore a guarantee for the establishment of a free and just society. If dispositions and paradigmatic, skewed perceptions are not radically changed, violence will escalate. It seems that more than a constitution is needed to establish peaceful coexistence and cooperation. Although Queen Elizabeth II was confident that Malaysia "will continue to show to the world that example of co-operation and goodwill between all races" (in Osterhammel 1997:113), the reality in South Africa's so-called Rainbow Nation is pointing to the opposite. Instead of cooperation and co-existence, \#MustFall Campaigns point to schismatic resistance and even violent opposition, questioning even ANC claims of messianic black empowerment.

If the argument is that violence is justified in order to inflict anxiety amongst the people representing the status quo, what is the alternative? If there is no solution and we are heading for a political cul de sac, how should we try to understand the seeming irrational demands in \#MustFall campaigns? 


\section{The \#MustFall campaigns: the global and international scenario and the link to xenophobia}

The \#MustFall campaigns are not isolated cases. The link with colonialism and the activist demands for colonialization must be understood within a more global perspective. According to San Juan (1999:113-115), transnational developments within the arena of international politics, American pluralism, worldwide racism and the phenomenon of anti-migrant xenophobia. Anti-campaigns are exponents of problematizing identity and the ideology of racism within multicultural imaginary. Anti-campaigns need scapegoats to justify the dissatisfaction of people suffering from discrimination, economic decline and deteriorating standards of living.

Transnational, globalised capitalism and its connection to archetypal postmodern cities (megalopolis), lead to dislocating and existential disorientation. Violent explosions, disillusionment, grassroots dissatisfaction with life, also the imperative for decolonisation, should be interpreted within the networking dynamics of global paradigmatic systems of thinking. "What is at issue ultimately is the failure of the "liberal democratic" free-enterprise system to deliver, this failure being indexed by the erosion of economic well-being, opportunity for advancement, social stability, and personal safety for people of all nationalities and the middle class generally. It is this profound crisis of market-centred liberal society, of multinational corporations and globalized capital that we are witnessing in events in California" (San Juan 1999: 113-114).

Another paradigmatic factor in the campaigns is suppressed existential anger as a legacy of apartheid.

In a television interview on the student protest action on campuses, the question has been asked: What do you mean by de-colonisation? The answer came: take the concept of colonisation: it means white supremacy, therefore - remove whites! Max Du Preez (2016:11) wrote an article in which he made the statement that the protest actions of students have become militant. The struggle is against "whiteness". The \#FeesMust Fall campaign has become \#WhitesMustFall. ${ }^{2}$

2 In Die Burger (27/09/2016) there was a picture of protesting people with a poster: "Black pain is a White commodity". 
The \#MustFall campaigns are intrinsically connected to existential racism. One can argue and say that in a semiotics of racialized discourse, preconceptual elements such as classification, order, value, and hierarchy are prevalent. Other components are: differentiation and identity, discrimination and identification; exclusion, domination, subjection, and subjugation; as well as entitlement and restriction. Thus, the conclusion by San Juan (1999:119): "Race is the mark of class, in the ultimate analysis." Social construction is related to classification; principally it enables racial differentiation while other factors are historically articulated with it to authorize various forms of racial exclusion. The latter is the core component of violent anti-sentiments.

Eloff (2016:14) poses the question: What is the driving force behind violent student riots? Black youth are disillusioned and dissatisfied with their daily, grassroots experience of twenty-two years. They feel still excluded despite the miracle of a new constitutional and political transition. The possibility has been mentioned that even the constitution must fall.

According to Eloff (2016:14), black youth are talking about "post-apartheidapartheid". Rising expectations amongst middle class blacks bump against the ceiling of "white control freaks". According to their experience, the new South Africa is still dominated by white supremacy. Whiteness and white privilege leads to anti-white sentiment. This anti-expression against white dominance is not seen by students as racism, but as justified prejudice (Eloff 2016:14). Therefore, the slogan: "remove whites". The basic need is to create spaces without white presence so that black students can talk about their disadvantaged predicament. Blacks should also occupy white spaces of control and administration at campuses.

The argument is that violence is justified in order to inflict anxiety amongst the people representing the status quo. The argument of the French journalist and philosopher Frantz Fanon that violence is a principle option for existential frustration is used to substantiate militant actions (Eloff 2016:14). The predicament is that this kind of principled violence exclude any form of dialogue and compromise. Their demand is to overthrow and oppose the new South Africa, even the principle of non-racism, as well as the idea of a constitutional settlement. They are totally against "rainbowism" (Eloff 2016:14). 
Decolonialization, as well as \#MustFall Campaigns, in their articulation of existential pain and anger, should be understood within the framework of another very sensitive issue: social prejudice and the paranoia of xenophobia. Because, if the campaigns and decolonising activism are becoming BlackWhite-polarisation in South Africa, it will become extremely difficult to come up with alternatives and meaningful reconstruction options in order to heal the South African society.

It becomes evident, that the \#MustFall Campaigns operate within the complexity of social prejudice. It can be linked to the phenomenon of xenophobia: fear for the other. Besides its critical stance on colonial, imperial exploitation with the side effects of inhumane cultural deprivation, \#MustFall Campaigns and the link to decolonising activism, should be understood against the background of other ideological issues within the international scenario. In this regard, the phenomenon of xenophobia is not an isolated South African issue. It can be linked to a global paranoia, namely that the unwanted stranger is threatening the me-position of selfassertion - the influx of Nigerians, people from Zimbabwe and Somalia are exploiting our job opportunities.

In the case of South Africa, the Blacks were the unwanted strangers in the apartheid dispensation. Now, in the so-called New South Africa, it seems that within the \#MustFall campaigns and decolonising activism, the "Whites" are becoming the unwanted strangers. "The other" is becoming the stumbling block not only for freedom and total liberation, "the other" is also the stumbling block for future social development and the quest for what has become the Western ideal of wealth and importance - the pursuit of happiness. In this sense, xenophobia is not merely a race issue; it is also an ideological issue embedded in our global market driven economies.

It will thus be argued, that the striving for personal wealth and the connection to the social utopia of a better life for all, is a subtle sub-text in many anti-campaigns. A good example is the xenophobic reaction of many wealthy countries and national governments in their response to the migrant and refugee crisis. The phenomenon of xenophobia in the refugee and migrant crisis will be used as an example how prejudice feeds hostile polarisation and contributes to the disruption of processes of social change, transformation and the restructuring of civil society. 


\section{4. "Fear for the other" as stumbling block for utopian happiness (better life for all)?}

The expectation of the peaceful transition $(1990$ - 1994) and the constitutional settlement gave substantial reason for hope among people, deprived from their dignity, that life will be better under an ANC government. Mandela became an icon of reconciliation. The miracle of a peaceful settlement, created the illusion under blacks and whites that now we will live "happily" together. But very suddenly, the illusion seems to be indeed a mirage. Violent anti-white campaigns and decolonising slogans seem to be the only alternative for disillusioned young blacks to escape from the so called "threatening colonists" (white supremacy).

Albeit, the complexity of decolonisation campaigns in the twenty first century, should be linked to other worldwide crises as well. One is the social and factor of global mobilisation and migration.

According to Polak (2014:1), homo sapiens is in essence a homo migrans. Throughout history people were on the move. One can even say that migration is a social phenomenon and part of human existence (Castles \& Miller 2009:299). However, what is currently happening is that migration has become a feature of our being human in the so-called global village. Migration is about a new mode of defining identity, diversification within mass pluralisation. ${ }^{3}$ It is challenging our understanding of notions like national states, "civil society", "democracy" and "human dignity.

The other factor is ideological, namely democratisation within the global quest for a better life for all

To my mind, the demand for a better life, is embedded in philosophical ideas about development (Fortschritt), progress, wealth, prosperity and future "happiness". The pursuit of happiness is a factor in the worldwide movement of migrating people in their search for freedom and dignity.

3 “Die „Super-Diversifizierung“ globaler Migration führt $\mathrm{zu}$ einem nicht mehr überschaubaren Ausmaß an Pluralisierung und Mobilität. Zeitgenössische Mobilitätsund Kommunikationsmöglichkeiten fördern „transnationale Migration und lassen Mehrfachzugehörigkeiten entstehen, die nicht mehr in die klassischen Formate von „Heimat" und „Fremde“ passen. Rund um den Globus findet eine „transnationale Revolution statt, die Gesellschaften und Politiken neu formt” (Polak 2014:3 ) 
Due to mobilisation, westernisation and globalisation, decolonisation should be viewed as a critical and anti-stance within the broader framework of a market driven economy and big-company capitalism (Big Brother). ${ }^{4} \mathrm{It}$ does not function independent from media-exposure. Its roots are deeply anchored in liberation thinking. It operates with the utopian idea that when one is free from all the social bullies, one will rediscover one's unique human dignity. This utopia is linked in a very subtle way to the ideology of the pursuit of happiness as projected by the affluent lifestyle of developed countries.

In 1776 the Founding Fathers of the United States established the right to the pursuit of happiness as one of the three unalienable human rights, alongside the right to liberty. This right to pursue happiness has become a close ally for developmental capitalism and economic expansion all over the globe. It is creating a mirage of wealth in even very poor countries. With the slogan "production and development bring about happiness and wealth", the utopia of a prosperity cult links wealth and education. These allies will help people to live happily afterwards in peace.

In this regard, Harari in his very recent publication, Homo Deus (2016:32), aptly points out: All people want to be happy. "Production is important because it provides the material basis for happiness. But it is only the means, not the end. In one survey after another Costa Ricans report higher levels of life satisfaction than Singaporeans." Without ignoring the plea of poor people for a better life and excellent education, Harari poses the intriguing question: "Would you rather be highly productive but dissatisfied Singaporean, or a less productive but satisfied Costa Rican?" (Harari 2016: 32).

The pursuit of happiness touches the very fibre of human existence: the quest for meaning and life fulfilment.

According to Harari (2016:35), the glass ceiling of happiness is held in place by two stout pillars, one psychological, the other biological. On the psychological level happiness is linked to the basic human drive for need satisfaction. Happiness depends on expectations created by paradigmatic

4 George Orwell's novel referring to the complexity of the exploiting power structures of political constellations (1949). 
frameworks and ideas. It is more subjective than objective. However, "We don't become satisfied by leading a peaceful prosperous existence. Rather, we become satisfied when reality matches our expectations." (Harari 2016:35).

On the biological level, need satisfaction and existential expectations regarding our being happy, are determined by "our biochemistry, rather than by our economic, social or political situation" (Harari 2016: 35). According to the "father of happiness", Epicurus, we are happy when we feel pleasant sensations and are free from unpleasant ones (In Harari 2016:35).

With reference to the ideology of wealth as a guarantee for happiness, people all over the globe move in their search for safety, stability, peace and dignity. Peaceful coexistence is an ingredient of the pursuit of happiness.

In his book on a brief history of humankind, Yuval Noah Harari (2011:15) refers to the fact that migration is an essential element of human existence. "Scientists also agree that about 70,000 years ago, Sapiens from East Africa spread into the Arabian Peninsula, and from there they quickly overran the entire Eurasian landmass."

In the February edition of the National Geographic Magazine (2008), ${ }^{5}$ Cynthia Gorney warned against the possible devastating effects of migration worldwide on local communities. Immigration has inevitable a destabilising impact on the constellation of traditional views on what a nation and citizenship is about. Migration has become a trans-national phenomenon and is evoking a kind of "transnational revolution". It brings about a new sense of civil connectivity and national identity.

However, the pursuit of happiness and global migration, also contribute to a global paranoia: the fear for otherness.

5 "Every year, hundreds of thousands of Central Americans cross illegally into Mexico, 400,235 , to cite one oddly precise estimate from the Mexican National Institute of Migration - along the country's southern border, which angles over 750 miles of river and volcanic slope and jungle at the top of Central America. Nobody knows exactly how many of those migrants are headed to the United States, but most put that figure at 150,000 or more a year, and the pace of illegal migration north has picked up dramatically over the past decade, propelled in part by the lingering aftermath of the 1970s and ' 80 s civil wars in Guatemala, El Salvador, and Nicaragua. In depictions of this modern Latin American migration into the United States, the image of a great wave is often invoked, and Mexico's southern border today feels like the place in distant water where the wave first rises and swells and gathers uncontainable propulsive force" (Gorney 2008). 
Without any doubt, the refugee crisis is about blunt fear and prejudice. It is about the fear for "overforeignization" (Überfremdung): the fear that home will become unrecognizable, because of foreign thinking and believing, strange languages and strange behaviour (Kunzig 2016:100). Albeit, the crisis reveals more than merely the phenomenon of prejudice and fear. It unmasks deep seated convictions about our being human, identity, paradigms and philosophical life views. The suffering of vulnerable refugees compels practical theological reflection to revisit the moral fibre that determines human behaviour and shapes attitudes in daily human encounters. In fact, the crisis probes into the dimension of human habitus, attitude, aptitude and mode of daily living within the dynamics of human relationships (Heidegger 1963: So-sein). It penetrates the existential dynamics of meaning and purposefulness.

Behzad Yaghmaian, a professor of political economy at Ramapo College of New Jersey, who wrote Embracing the Infidel: Stories of Muslim Migrants on the Journey West (in Vick 2015:31), remarks as follows: "Because of globalisation, you have awareness of life elsewhere in the world. That's crucial now. So you move." (The dynamics of mobility: moving to a better world - pursuit of happiness, cult of prosperity and wealth).

But the crucial point is: the utopia of elsewhere is often a fading mirage.

\section{Global paranoia and the retreat of retrotopia}

Zigmunt Bauman (2016:124) responds in a new publication to the current refugee crisis and the shiftlessness of developed countries to deal with global threat and violence. He calls his approach to contemporary, global realities: retrotopia.

Bauman is reacting to Thomas Moor's notion of "utopia". Utopian euphoria is always elsewhere, but in reality, nowhere. So people start to retreat. By retrotopia ${ }^{6}$ is meant: the awareness of space and place that is "not-here". Not-here, not because it does not exist. It exists already, but unfortunately,

6 Retrotopia deals with existential disillusionment. "Die Enttäuschung wartet in der Zukunft. Statt einer sorgenfreien Zeit erleben wir eine Katastrophe nach der anderen: Terrorimus, Finanzkrise, Wirtschaftsstagnation, Arbeitslosigkeit, Prekarität" (Bauman 2016:124). Instead of hope for improvement in future, people become victims of anxiety. 
is not yet recognised by many developed countries in the West (Bauman 2016:124). Retrotopia is in opposition to utopia; it symbolises the yearning for a past world of confidence, humane trust, safety, and conformity (einer sicheren Weltder Konformität) (Bauman 2016:124). Bauman refers to the fact that when he was young, he shared the progress-ideology (the utopia of Der Fortschritt) of optimistic future projections. He thought Oscar Wild was right in his view that progress will bring about the utopia of a better life for all. However, young people, especially in Germany, expect nothing new and better in the future: no gain, only loss (Bauman 2016:124).

Retrotopia is a yearning backwards while the present is becoming a prison and people are forced to move forward. Unfortunately, blindfolded without imaginative anticipation for something new and different. They are becoming emotional robots filled with disillusionments and anger. Citizens are falling back on national exclusiveness and are losing their cosmopolitical awareness (Bauman: kosmopolitische Bewusstsein).

One could trace back in decolonising campaigns this loss of future excitement. It is even combined with an unconscious level of cosmopolitical awareness of global otherness within cultural diversity. But, due to suppressed forms of anger, this cosmopolitical awareness is often expressed in militant activism. Anti-white sentiment has become the lightning distractor for deep seated experiences of discriminatory maltreatment and feelings of inferiority. Whiteness means superiority and blackness failure.

The problem of decolonisation is clearly complex and intertwined with global processes of intercultural changes. The whole migration crisis all over the globe, together with poverty, is bringing about civil societal disillusionment, a feeling of powerlessness amongst many in Africa. Migrants are seeking a better lifestyle "elsewhere". In Africa, elsewhere is often a South African Egoli. And, in South Africa, poor people feel threatened by Nigerian exploiters and Somalian refugees. It even gives rise to political campaigns with populist undertones.

\section{The politics of fear: "galloping populism"}

The global paranoia regarding the migrant crisis is creating on a political level a politics of fear and exclusive self-maintenance. 
The politics of fear is even driving campaigns for presidency in the United States. Donald Trump, in his campaign for presidency, said on Twitter that he would soon be known as Mr. Brexit (Shuster 2016:28). A politics of fear leads inevitably to what Jean-Claude Juncker, president of the European Commission, calls "galloping populism” (Shuster 2016:26).

"Galloping populism" is hitting Europe like a tsunami. Movements like the Sweden Democrats, the National Front in France, the Party for Freedom in the Netherlands and other voices on the far right calling for their once open countries to close up and turn inward. In the United States it is leading to "Trumpism". Rightist parties align with Republican presidential candidate Donald Trump in what they encourage voters to fear: "migrants taking jobs, Muslims threatening your culture and security, political correctness threatening your ability to speak your mind and, above all, entrenched elites selling out in the service of the wealthy and well-connected: (Shuster 2016:26).

The cultural dilemma is illustrated by the Brexit debacle in Britain.

In an article in Time, Dan Stewart (2016:7) warned on the $24^{\text {th }}$ of June that "emotion and immigration could drive Britain to exit the E.U." The Leave vote ("Brexit") became a reality on Friday the $24^{\text {th }}$ of June. Immediately after the news the pound became vulnerable and worldwide stock exchanges became nervous. The point is: Brexit is an emotional and habitual issue. It is fired by a kind of conservative populism and the fear for the stranger. "Immigration is the chief issue of concern for voters in this election" (Stewart 2016:8).

Due to processes of globalisation, all human beings, whether one is living in Paris, New York or Cape Town, are involved in a kind of global paranoia: citizens in national states fear the incoming refugees and migrants and respond with resistance and prejudice. On the other hand, a collective guilt is developing: but they are human beings and we should treat them with dignity and care! What is a proper response within the paradox of fear (resistance) and welcoming outreach (integration)?

It is clear that any pastoral response should accept the insoluble reality of the attempt to isolate and safeguard own territory. On the other hand, human beings are not merely territorial animals. We live according to values by which we interpret the meaning of life. Thus, the wavering 
realistic paradox: limitation and integrity (Grenzen und Ehrlichkeit) (Amann 2015:28), prejudice and integration.

The point is, that despite the fact that a solution is not evident, one must confess and say: "Many of the spiritual tensions we encounter are primarily situated within the realms of paradox, antinomy or polarity" (Hernandez about H. Nouwen 2012:2). With paradox is meant the illusion of the opposite/contradiction. "The mind's first step is to distinguish what is true from what is false. However, as soon as thought reflects on itself, what it first discovers is contradiction" (Camus 1965:20). It seems as if the opposites exclude one another. In fact, they complement one another in order to describe complexity and the realm of faith. "To give a basic definition, a paradox is characterized by a self-contradictory proposition that can appear absurd or nonsensical. The absurdity is embedded in the rhetoric" (Hernandez 2012: 2).

On a paradigmatic level, it becomes paramount for a hermeneutical approach, to understand life crises within the complexity of paradoxical polarisation. This polarisation is described by Kunzig (2016:100-115) as the oscillation between fear of otherness (the self-maintaining I) and the ethos of welcoming (the inclusive we) ${ }^{7}$. Thus the polarity: segregation/separation - integration/inculturation. In South African terminology, it is about the political paradox and complexity of Zebra nation - Rainbow Nation.

In most cases polarisation based on fear and prejudice lead unfortunately to inflation of compassion, namely indifference and apathy. One sees this danger of apathy in the current migration crises. This is the case not only outside Syria, but from inside as well; “...the limits of compassion, coupled with wariness of Muslims, comes into remorseless focus, even in an immigrant nation" (Vick 2015:34). One can actually call the limitation of compassion as a crisis of compassion deficit.

The \#FeesMustFall dilemma, will have an impact on the quality of social empathy. It is evident that Black-White polarisation fuels racial based xenophobia. It has also been stated that an instant solution to student's \#FeesMustFall campaigns is not possible. In such a situation of no exit out

7 "It's not just Germans. But Germans not so long ago carried that fear to its most vicious extreme. As a result, many of them still feel its reflection: fear of themselves" (Kunzig 2016:115). 
of a polarised dilemma, Bauman (2016:122) makes an emphatic statement: the only option is solidarity ${ }^{8}$; solidarity not merely as a moral principle, but as an expression of compassionate being-with.

\section{A conjunctive faith: embracement, solidarity and dialogue?}

It is the conviction of Bauman (2016:125) that the refugee dilemma boils down to dispositions of suspicion and distrust. People don't trust one another. We are becoming enemies of one another within a global rat race of competition and exploitation. The other becomes marginalised and stereotyped.

Instead of stereotyping the other, they should be personified again. The other should be treated as a unique human being and not as representative of a cultural category, race or religion (Bauman 2016:125). And in order to do that, more than a polity of tolerance is needed, because tolerance is most of times merely brutal indifference. Thus, Bauman's proposal for solidarity: the challenge to embrace the other as partner for dialogue and to invite him/her to an encounter through which one can better understand the intention behind the other's behaviour.

Without any doubt this option of Bauman has got implications for a pastoral encounter. In the option of solidarity, embrace and dialogue, brings the quest for compassion and a spirituality of cruciform love becomes paramount. Solidarity without compassion can contribute to a crisis of authenticity and sustainable endurance.

One can further argue that a "spirituality of dialogue" presupposes an encounter of embracement as expression of an existential conjunction between two different human beings. In this regard, one can say that a Christian spirituality of compassion operates as a "conjunctive faith" that informs the style of caregiving in ministry. Spirituality is thus viewed as the "ability to embrace ambiguity and paradox; a sense of truth that is multiform and complex; post-critical receptivity ("second naiveté"), and readiness to participate in the reality expressed in symbols, myths and rituals of one's own tradition; genuine and disciplined openness to

8 "Es gibt keinen anderen Ausweg aus die Krise, in der die Menschheit sich befindet, als Solidarität.” (Bauman 2016:122). 
the truths of communities and traditions other than one's own (not to be equated with relativism); movement from the prevalence of certainty to the centrality of trust" (Schipani and Bueckert 2009:317-318).

A readiness to participate, translated into the language of Christian solidarity, can to my mind best be demonstrated by two praxis categories in the tradition of cura animarum: hospitable presence and compassionate being-with. The church has nothing else to offer when pastoral caregivers are prepared not to migrate to "elsewhere", but to participate and to become engaged in the turmoil of political and cultural chaos.

\section{Hospitable presence: towards a practical theology of compassionate being-with}

Indirectly, \#MustFall campaigns puts a question mark behind any form of exclusive supremacy and hierarchical domination. Immediately such a critique has consequences for ecclesial structures based on the maintenance of power and xenophobic exclusivity. Thus, the focus on an operative ecclesiology ${ }^{9}$ (Yves Congar in Bergson 2015). The ministerial challenge is to see the\# MustFall crisis as a sign of our time. The crisis of social disillusionment also questions traditional denominational ecclesiologies and should thus be viewed as an opportunity to create public places and spaces for dialogue and encounters of embracement in order to bridge the schisms in our very frail South African society. The \#MustFall campaigns and upcoming new forms of racisms and xenophobic scepticism should be viewed as opportunities to contextualise practical theological theories and ministerial engagements within civil complexities of life (Migration als Ort der Theologie, Kessler 2014).

The core ministerial challenge is captured by former Archbishop Desmond "We were involved in the struggle because we believed we would evolve a new kind of society. A caring compassionate society. At the moment

9 With operative ecclesiology is meant performative actions of being the church within concrete contexts. It reflects on ecclesial matters not merely from the viewpoint of denominational traditions and dogmatic confessions, but within communal life systems. Ecclesiology may be studied inductively and can thus draw support from various other disciplines, such as political science, history and sociology. See Bergson 2015. 
many, too many, of our people live in gruelling demeaning, dehumanising poverty. We are sitting on a powder keg. We really must work like mad to eradicate poverty" (Tutu 2004:33).

According to (Korsch 2011:342). ${ }^{10}$ life as object of practical theological reflection, implies a metaphoric understanding (hermeneutics) of daily life events in order to open up new future options for human self-realisation. But, if life is threatened by inhumane structures and skewed political agendas, how can practical theology, specifically pastoral caregiving, contribute to change and the healing of life? This is more or less the question the \#MustFall campaigns are putting on the agenda of pastoral theology and ministerial approaches.

How should the pastoral ministry as outcome of a practical theological engagement, understand and interpret the current \#MustFall Campaigns (hermeneutical approach)? Taking into consideration that the political turmoil and social unrest is to a large extent based on fear and anger, what is an appropriate alternative option for communities of faith?

Instead of xenophobia, the metaphors of host and hospitality in pastoral caregiving should be promoted. Instead of fear for the stranger, the principle of philoxenia should be applied: the mutuality of "brotherly" love. The praxis of hope presupposes the "office of deacon" and the virtue of hospitality in order to establish caregiving as an exponent of diakonia.

Christian hospitality counteracts the social stratification of the larger society by providing an alternative based on the principle of equality; everyone is welcome regardless of background, status, gender or race. Within the intercultural framework of community care, the challenge to the pastoral ministry is to provide "hospitals" (xenodochia), safe havens (monasteries of hope, places of refuge) where threatened people can become whole again. "To be moral is to be hospitable to the stranger" (Ogletree 1985:1).

10 The basic thesis of Korsch (2011:342) is that life is about self-fulfilment; Leben ist Selbststeigerung. "diese verfasstheit des Lebens betrifft sowohl die materiellen Erscheinungsformen organismischer Art-als auch dieMetaphorik, dieden Lebensbegriff so universal anwendbar macht für zukunftsoffene Selbstorganisationsprozesse" (Korsch 2011:342). 
The metaphor of the host communicates sharing, welcoming, embracement, inclusive communality (the church as the hospitium of God).

A compassionate community is about the challenge to provide "hospitals" (xenodochia), safe havens (monasteries of hope, places of refuge) where threatened people can become whole again. Hospitality is actually about a public virtue: hospitium publicum.

Hospitium publicum is about creating spaces for distressed, homeless, displaced and dislocated people; spaces where they can be helped to come in contact with their very being in order to re-orientate within the existential experience of disorientation. It is about a space wherein one can be reconnected to a meaningful framework that contributes to a sense of meaning, purposefulness and communion. This moment of reorientation can be described as the exposure to synchronicity (Jaworski 1996). ${ }^{11}$

Instead of the attempt to achieve something in the pastoral encounter, the pastoral encounter is about the happenstance of co-existence wherein a kind of paradoxical attractiveness creates a moment and state of life fulfilment despite experiences that point to the opposite. Synchronicity can then be described as a state of "commitment and surrender" wherein we begin to experience what is sometimes called "synchronising" (Jaworski 1996:14); moments of being-with without rational agendas; spaces of sharing and experiencing without verbal expressions; co-existence as coincidence of caring outreach; exchange of meaning.

Synchronisity should be supplemented by what is known in wisdom thinking as praxis pietatis.

In order to summarise, one can say that praxis pietatis entails the following two pastoral interventions:

\section{Enfleshment of neighbourly love (Calvin)}

To exist means to coexist. Coexistence is in essence an exemplification of unconditional love (agapé). However, coexistence is not blind for the

11 According to Jaworski (1996:ix), synchronicity is more or less the same as what Jung had described as a meaningful coincidence of two or more moments where something other than the probability of a chance is involved. Synchronicity operates on the basis of paradox: opposing forms of meaning can create new forms of existential significance. 
realities of life. Coexistence is a category that deals on the one hand with critical distance (critical realism, objectivity), and, on the other hand, with compassionate solidarity (unconditional passion, engagement).

The option of coexistence is more or less the option and route which Calvin applied in his engagement with the refugee crisis and social turmoil in Genève.

According to Calvin (in Busch 2007:74), “...we must live together in a family of brothers and sisters which Christ has founded in his blood; and with very hostility he gives the opportunity to resist hostility."

Fundamentally, in his view on the equal value of human beings, Calvin operated from the perspective of "neighbourly love" as the sound principal for an inclusive approach to social and human issues. "The word neighbour includes all men living; for we are linked together by a common nature... The image of God ought to be particularly regarded as a sacred bond of union, but, for that very reason, no distinction is here made between friend and foe, nor can the wickedness of men set aside the right of nature" (Calvin 1854:116).

In his sermon on Galatians 6:9-11, it is evident that the outsider, stranger and other, function as a kind of mirror and looking glass for a community based church. "We cannot but behold our own face as it were in a glass in the person that is poor and despised...though he were the furthest stranger in the world. Let a Moor or a barbarian come among us, and yet inasmuch as he is a human, he brings with him a looking glass wherein we may see that he is our brother and our neighbour" (Quoted by Busch 2007:75). According to Busch (2007:75), this concrete spiritual insight of Calvin is the source of his interest in social and economic affairs. The command for neighbourly is the thrust of Calvin's "spiritual humanism" (my interpretation).

\section{Compassion and solidarity as merciful being-with}

Being-with presupposes a very specific stance and disposition within political structures and civil societal attempts to deal with the complexity of polarisation: the integration - segregation tension. In this regard, the church can play an important role by trying to create constructive dialogue and provide public forums where different groups can meet in 
order to discuss various options for meaningful cooperation on the basis of mutual sharing, cultural exchange, equal partnership and co-humane trust building. In order to establish such a forum, it should be based on the principle of peaceful coexistence. This attempt should be performed as an exemplification of sensitive participation and cruciform love.

The latter option is not without any dangers. Peaceful coexistence can easily become a façade for separation and eventual disintegration of peaceful interventions. Kunzig (2016:115) refers to the notion of a "parallel society" that eventually can become a divided society. "In a word: Parallelgesellschaften, or "parallel societies". "The part of cities where you wouldn't know you were in Germany" (Kunzig 2016:112)."

Within an ecclesial environment, peaceful coexistence is linked to the koinonia and diakonia of the community of believers. Within the framework of koinonia, coexistence presupposes mutual exchange on the basis of an ethos of sacrificial love and merciful outreach.

\section{Towards an ecclesial penetration of the polarised dilemma: the perichoresis ${ }^{12}$ of mercy}

The Christian poet Lactantius (in Davies 2001:235), who lived from the third to the fourth century, combined the concept of compassion,

12 The word perichoresis comes from two Greek words, peri, which means "around," and chorein, which means "to give way" or "to make room (from Greek: $\pi \varepsilon \rho \iota \chi \omega ́ \rho \eta \sigma \iota \varsigma$ perikhōrēsis, "rotation"); it describes the relationship between each person of the triune God (Father, Son, and Holy Spirit). The word "circumincession" (later circuminsession) is also used to mean the same idea. I am using it not to describe a triune relationship but as an indication of how the spirituality of compassion as outcome of Christology and pneumatology, describe and present the interpenetration of the Spirit of God in cosmic events and systemic networking of human relationships; it is an indication of exchange in order to make room and space, to influence; it indicates a kind of mutual intersecting or interpenetration.

The word perichoresis could be translated as "rotation" or "a going around." Perichoresis is not found in the Greek New Testament but is a theological term used in three different contexts. In the first, perichoresis refers to the two natures of Christ in perfect union within the same Person. In the second context, perichoresis refers to the omnipresence of God as He "intersects" with all creation (see Acts 17:28). In the third context, it refers to the mutual intersecting or "interpenetration" of the three Persons of the Godhead and may help clarify the concept of the Trinity. It is a term that expresses intimacy and reciprocity among the Persons of the Godhead. [Online] Available: http://www. gotquestions.org/perichoresis.html. [Accessed on 17/11/2015]. 
misericordia, to the notion of humanitas. He viewed compassion as a corporate strength granted by God (hunc pietatis adfectum) in order that humankind can show kindness to others, love them and cherish them, protecting them from all dangers and coming to their aid (Lactantius in Davies 2001:35). Compassion thus creates a bond of human society and displays human dignity. "Humanitas is to be displayed to those who are 'suitable' and 'unsuitable' alike, and 'this is done humanely (humane) when it is done without hope on reward'" (Lactantius in Davies 2001:35).

According to Martha Nussbaum, compassion should be preferred in order to express "the basic social emotion" (In Davies 2001:238), connecting both the cognitive and the affective. For Nussbaum compassion is in fact a certain kind of reasoning, a certain kind of thought about the well-being of others.

Compassion in a Christian understanding of a theology of compassion is essentially determined by Christ's vicarious suffering (Gärtner 1978:724). His vicarious suffering took place ephapax, once for all (Heb 7:27). In the Synoptic gospels, pascho is used within the framework of the passion of Christ. Our sympathy and compassion is determined by the fact that Christ exercises compassion (Gärtner 1978:722). Instead of the emotional interpretation of compassion by the Stoics and their emphasis on the fact that passion (pathe $)$ should be overcome in order that the ideal of "dispassionateness" (apatheia) may be attained, active and practical compassion (sympaschō) is an issue of faith in Christ (1 Cor. 12;26; Heb. 10:34). (Gärtner 1978:724). In this regard, compassion should be connected to a ministry of serving (diakonēo) (Gärtner 1978:724).

This kind of ministry should be a mode of interpenetration and infiltration within the antinomy and paradox of fear and compassion without the selective morality to side only with the victim without negotiating and encountering the perpetrator. This kind of perichoresis of unconditional love is what cura animarum (care and cure of human souls) is about.

\section{Conclusion}

As mortal beings, we cannot escape transience, vulnerability and conflict. Caregivers in communities of faith should therefore become agents of hope 
if they want to do what Socrates had in mind: To be a healer of the "soul" (iatros tés psuchés) (in Oden 1983:187). The pastoral caregiver becomes the in-between person (Aristotle), between pity and fear, interpenetrating this paradoxical condition with the perichoresis of compassion: making room (home) for the homeless and a hospital space for the victims.

The \#MustFall campaigns should not be met with resistance and enmity. A pastoral hermeneutical approach hinges on the quality of a hospital presence as forum for conflicting factions to meet for dialogue and to be exposed to the synchronicity of "paradoxical attractiveness": the aesthetics of black anti-white resistance and white anti-black enmity.

Derrida (2001:16-17) asserts: "Hospitality is culture itself and not simply one ethic among others. Insofar as it has to do with the ethos, that is, the residence, one's at home, the familiar place of dwelling, as much as the manner of being there, the manner in which we relate to ourselves and to others, to others as our own or as foreigners, ethics is hospitality; ethics is entirely coextensive with the experience of hospitality, whichever way one expands or limits that". To a certain extent, hospitality reintroduces a kind of social paradox: unconditional loves becomes conditional; it focuses conditionally on the outsider in order to make outsiders insiders even beyond the categories of juridical equality; it functions outside of right, above what is juridical (Derrida 2001).

\section{Bibliography}

Amann, M et al. 2015. Das neue Deutschland. In, Der Spiegel, Nr. 36, 29/08/2015, pp. 18-29.

Bauman, Z 2016. Nationalismus ist ein Ersatz. Spiegel-Gespräch. In: Der Spiegel, Nr. 36/3.9.2016, 122-125.

Bergson, E 2015. Catholicity Challenging Ethnicity. An Ecclesiological Study of Churches in Post-Apartheid South Africa. Uppsala: Uppsala University.

Busch, E 2007. A General Overview of the Reception of Calvin's Social and Economic 'Thought'. In E. Dommen and J. D. Bratt (eds.), John Calvin Rediscovered. Louisville KY: Westminster John Knox. 
Calvin, J 1854. Commentaries on the Epistles of Paul to the Galatians and Ephesians. Edinburgh: Printed for the Calvin Translation Society, T. Constable.

Castels, S, Miller, MJ 2009. The Age of Migration. International Population Movements in the Modern World. New York/London: Castillo Guerra, J.E. 2014.

Camus, A 1965. The Myth of Sisyphus. London: Hamish Hamilton.

Davies, O 2001. A Theology of Compassion. Metaphysics of Difference and the Renewal of Tradition. Grand Rapids/Cambridge: William B. Eerdmans Publishing Company.

Derrida, J 2001. On Cosmopolitanism and Forgiveness. London: Routledge. Dostoyevski, F 1973. The Idiot. Harmondsworth: Penguin Books.

Du Preez, Max 2016. Dis nou \#WhitesMustFall. In Die Burger, Dinsdag 11 Oktober, 11.

Eloff, T 2016. \#FeesMustFall is net die oortjies van die seekoei. In Die Burger, Donderdag 13 Oktober, 14.

Gärtner, B Suffer (paschō). In C. Brown (ed.), Dictionary of New Testament Theology, Volume 3. Exeter, Paternoster Press, pp. 719-725.

Gorney, C 2008. Mexico's Other Border. [Online].Available:

http://ngm.nationalgeographic.com/2008/02/mexicos-southern-border/ cynthia-gorney-text. [Accessed: 16/11/2015].

Gregan, E 2016.Twee kante van die munstuk. In Die Burger, Saterdag 15 Oktober 2016, 10.

Harari, YN 2011. Sapiens. A Brief History of Humankind. London: Vintage Books.

Harari, YN 2016. Homo Deus. A Brief History of Tomorrow. London: Harvill Secker.

Hernandez, W 2012. Henri Nouwen and Spiritual Polarities. A Life of Tension. New York: Paulist Press. 
Janse Van Rensburg, A 2016. Die storie agter die protes. In: Die Burger, By, Saterdag 18 Oktober, 1-6.

Jaworski, J 1996. Synchronicity. The Inner Path of Leadership. San

Francisco: Berrett-Koehler Publishers.

Korsch, D 2011. Life science - gelebte Religion - Theologie als

Lebenswissenschaft. In: T. Klie, M. Kumlehn, R. Kunz, T. Schlag (hrsg.), Lebenswissenchaft Praktische Theologie?! Praktische Theologie im Wissenschaftsdiskurs. Band 9. Berlin/New York: de Gruyter, pp. 341-344.

Kunzig, R 2016. The New Europeans. In National Geographic, October 2016, 82-115.

Oden, TC 1987. Pastoral Theology. Essentials of Ministry. San Francisco: Harper \& Row.

Loomba, A 1998. Colonialism/Postcolonialism. Routledge: London and New York.

Ogletree, TW 1985. Hospitality to the Strangers. Dimension of Moral Understanding. Philadelphia: Fortress Press.

Orwell, G 1949. Nineteen Eighty-Four (1984). London: Secker \& Warburg. Osterhammel, J 1997. Colonialism. A Theoretical Overview. Princeton/ Kingston: Markus Wiener Publishers/Ian Randle Publisher.

Polak, R 2014. Migration als Ort der Theologie. In: T. Kessler (ed.) Migration als Ort der Theologie. Regensburg: Verlag Friedrich Pustet, pp. 1-20.

Ramphele, M 2012. Conversations with My Sons and Daughters. Penguin Books: Johannesburg.

San Juan, E 1999. Beyond Postcolonial Theory. New York: St. Martin's Press.

Schipani, DS, Bueckert, LD 2009. Introduction. In: DS Schipani, LD Bueckert (eds.), Interfaith Spiritual Care. Understanding and Practices. Kitchener: Pandora Press, 315-319.

Shuster, S 2016. Fear and Loathing. In: Time, vol. 187, n0 3, pp. 28-33. 
Shuster, S 2016. Europe Swings Right. In: Time, Vol. 188, No. 13/2016, pp. 24-29.

Stewart, D 2016. The Brief. Emotion and immigration could drive Britain to Exit the E. U. In: Time, vol. 187, no. 24, pp. 7-8.

Synchronicity. [Online] Available: https://en.wikepedia.org/wiki/ Synchronicity. [Access 16/09/2016].

Tutu, D 2004. Nelson Mandela annual Lecture. [Online]. Available: http:// nelsonmendela.org/uploads/files/NMF_Lecture_Book_small.pd. [Accessed 20/09/2014].

Vick, K 2015. The Great Migration. In: Time. Special Report. Exodus. The Epic Migration to Europe \& What Lies Ahead. October 19, 2015, pp. 26-34.

Vick, K 2015. Angela Merkel. Chancellor of the Free World. In: Time, vol. 186, no. 25-26, pp. 26-51. 